\title{
STUDI PENANGANAN KOMPLAIN PASIEN DI INSTALASI RAWAT JALAN (IRJ) RSUD DR. SOETOMO
}

\author{
Muhadi* \\ * Dosen S1 Administrasi Rumah Sakit STIKES Yayasan RS Dr.Soetomo \\ Surel : muhadimuzani15@gmail.com
}

\begin{abstract}
ABSTRAK
Rumah Sakit Umum Daerah Dr.Soetomo sebagai pusat rujukan nasional di Jawa Timur mengalami peningkatan jumlah kunjungan rata-rata pasien setiap tahun. Proses pelayanan pasien secara berjenjang, menjadikan Rumah Sakit Umum Daerah Dr.Soetomo menjadi rujukan terkahir pasien. Di era JKN berbagai permasalahan semakin banyak yaitu tentang keluhan pasien berobat di rumah sakit semakin meningkat. Penelitian ini menggunakan pendekatan kualitatif. Pihak rumah sakit dan pasien di wawancarai tentang model penanganan keluhan. Penelitian bertempat di instalasi rawat jalan Rumah Sakit Umum Daerah Dr. Soetomo pada tahun 2015. Pasien mengeluh tentang antrian yang lama dan sikap petugas yang kurang responsif. Pasien merasa kesulitan menyesuaikan persyaratan administrasi pasien BPJS kesehatan dengan model kepesertaan lama atau asuransi kesehatan. Sosialisasi yang kurang menyebabkan informasi yang beredar mengenai prosedur pendaftaran dan pemanfaatan BPJS kesehatan tidak relevan dan membingungkan. Akibatnya tidak jarang staf rumah sakit menerima komplain atau kemarahan pasien, dituduh mempersulit, bahkan dituding mencari keuntungan. Tidak sedikit juga masyarakat yang mendatangi rumah sakit bukan untuk berobat melainkan untuk menanyakan mengenai perihal BPJS, sebagaimana terjadi di RSUD Dr.Soetomo. Implementasi program BPJS kesehatan bersinggungan langsung terhadap pasien yang datang berobat di rumah sakit. Peningkatan jumlah kunjungan pasien mengakibatkan hampir disetiap prosedur pelayanan di rumah sakit dikeluhkan pasien, mulai dari ruang mendatangi bagian informasi sampai dengan pasien mengambil di loket obat. Kebanyakan pasien memiliki keterbatasan informasi terkait pengaduan jika mereka mengeluhkan masalah yang berkaitan dengan pelayanan di poli. Maka diperlukan keterangan yang jelas dan sosialisasi tentang layanan pengaduan masyarakat baik melalui spanduk maupun poster untuk memudahkan mereka.
\end{abstract}

Kata Kunci : Penanganan Komplain, BPJS Kesehatan

\begin{abstract}
Regional General Hospital Dr.Soetomo as a national reference center in East Java has increased the average number of visits patients each year. Patient care process in stages, making Dr.Soetomo Regional General Hospital became the last referral patients. JKN various problems in the era of a growing number of complaints is about the patient's treatment in hospitals is increasing. This study used a qualitative approach. The hospital and the patients are interviewed about the complaint handling model. The research took place in the installation outpatient Regional General Hospital Dr. Soetomo in 2015. Results: The patient complained about long queues and those with less responsive attitude. Patients find it difficult to adjust the administrative requirements with a model patient health BPJS long membership or health insurance. Socialization is less likely to cause the information
\end{abstract}


circulating on the procedure of registration and utilization of health BPJS irrelevant and confusing. As a result it is not uncommon hospital staff received a complaint or anger the patient, it is alleged difficult, even accused of profiteering. Not a few people who went to the hospital for treatment, but not to ask about the subject BPJS, as happened in hospitals Dr.Soetomo. Conclusions: Implementation of the program BPJS direct influence on the health of the patients who come for treatment at the hospital. Increasing the number of patient visits resulted in almost every service procedures at the hospital complained of patients, ranging from space came up with a piece of information on counter medications the patient is taking. Suggestion: Most patients have limited information regarding a complaint if they complain of problems relating to the service in poly. It would require a clear and socialization of public complaints about the service either through banners and posters to facilitate them.

Keywords: Complaint Handling, BPJS Health Assurance

\section{PENDAHULUAN}

Jaminan Kesehatan Nasional akan dimulai pada tahun 2014 yang secara bertahap menuju ke universal health coverage. Tujuan Jaminan Kesehatan Nasional secara umum yaitu mempermudah masyarakat untuk mengakses pelayanan kesehatan dan mendapatkan pelayanan kesehatan yang bermutu. Perubahan pembiayaan menuju ke universal coverage merupakan hal yang baik namun mempunyai dampak dan risiko sampingan.

Perkembangan rumah sakit yang semakin maju membuat pihak manajemen rumah sakit semakin mempersiapkan pelayanan yang berkualitas agar tercipta kepuasan pasien. Kepuasan dirasakan oleh seseorang yang telah mengalami suatu hasil (outcome) yang sesuai dengan harapannya. Kepuasan merupakan fungsi dari tingkat harapan yang dirasakan dari hasil kegiatan. Apabila suatu hasil kegiatan melebihi harapan seseorang, orang tersebut akan dikatakan mengalami tingkat kepuasan yang tinggi (highly satisfied). Apabila hasil kerja tersebut sama dengan yang diharapkan, seseorang dikatakan puas (satisfied). Akan tetapi apabila hasil tersebut jauh di bawah harapan, seseorang akan merasa tidak puas (dissatisfied).

Rumah sakit berusaha untuk memanfaatkan sumber daya yang ada dengan optimal dan meniminalisir setiap bentuk keluhan pasien yang datang dengan memberikan pelayanan yang terpadu. Pergeseran tujuan pergerakan rumah sakit dari rumah sakit social menjadi ekonomi sosial memberikan dampak tersendiri bagi pelayanan di rumah sakit, menuntut pihak manajemen untuk bersaing secara kompetitif dalam mengelola rumah sakit (Afriani, 2012). Pasien yang merasa kurang puas terhadap kinerja pelayanan akan mengeluh dan mengungkapkan respon yang negatif bagi pihak rumah sakit terlebih khusus dokter. Maka jika terdapat keluhan pasien kemudian pihak rumah sakit mampu mengatasi dengan cepat, tepat dan tanggap, pasien akan merasa senang (service recovery).

Pelanggan yang mengeluh bisa menjadi loyal dan tenang. Hasil penelitian oleh Afriani (2012) di Rumah Sakit Fatmawati yaitu jenis keluhan yang diterima oleh karyawan rumah sakit diantaranya proses administrasi pasien, pelayanan dokter dan perawat, tariff dan fasilitas rumah sakit. Keluhan langsung di tangani oleh bidang kehumasan, menerima keluhan dan mencari solusi penanganan. Keluhan pada umumnya masih kurang efektif dan belum berjalanan sesuai predur yang ada. Rumah Sakit Umum Daerah Dr.Soetomo Surabaya sebagai pusat rujukan nasional khususnya di Jawa Timur mengalami peningkatan jumlah kunjungan pasien. Rumah Sakit Umum Daerah 
Dr.Soetomo memiliki unit promosi kesehatan rumah sakit (PKRS) dan humas RSUD Dr.Soetomo dalam penanganan keluhan pasien yang tergabung dalam satu unit. Humas sebagai penghubung lansung antara pasien dengan pihak rumah sakit menjadi jembatan mediator dalam memberikan informasi yang akurat dan tepat secara dua arah.

Berdasarkan hasil evaluasi implementasi BPJS kesehatan per Juli 2014 BPJS terdapat berbagai masalah diantaranya resiko tuntutan dan teguran bagi rumah sakit yang tidak melaksanakan pelayanan sesuai aturan pelayanan relatif besar. Dokter merasa dikurangi hak profesionalisme dan juga hak atas jasa medis. Keluhan ketersedian obat dari pasien belum tertangani dengan baik. Berdasarkan penjelasan tersebut, maka peneliti ingin mempelajari pelaksanaan JKN melalui perubahan atau perbedaan distribusi penanganan keluhan pasien sebelum dan sesudah penerapan JKN pasien di Rawat Jalan RSUD Dr. Soetomo tahun 2014. Penelitian ini berupaya untuk memahami tentang bagaimana keluhan pasien tentang BPJS kesehatan dan manajemen penanganan pasien oleh rumah sakit.

\section{METODE}

Penelitian ini menggunakan metode penelitian kualitaif yang bersifat deskriptif. Penelitian kualitaif yaitu langsung turun ke rumah sakit untuk memperoleh data dan informasi yang mendalam mengenai penanganan komplain di instalasi rawat jalan RSUD Dr.Soetomo. Peneliti mendeksripsikan hasil penelitian bedasarkan hasil wawancara mendalam dengan informan di lapangan. Analisis data menggunakan pendekatan kualitatif karena langsung mengaitkan kondisi di lapangan dengan kemampuan unit penanganan complain. Informen diperoleh berasal dari rumah sakit sebanyak 4 orang dan 5 orang berasal dari pasien yang berkunjung.

\section{HASIL DAN PEMBAHASAN}

Definisi respon time adalah waktu yang diperlukan untuk mendapatkan pelayanan pertama, sedangkan waktu penyelesaian yaitu waktu yang diperlukan untuk menyelesaikan urusan saat itu atau mendapatkan hasil (billing system, paper less, pemeriksaan khusus, pemeriksaan laboratorium tergantung banyaknya pasien dan berat ringannya kasus). Kurun waktu penyelesaian pelayanan di RSUD Dr.Soetomo dapat dijelaskan pada tabel berikut ini :

Tabel 1. Kurun Waktu Penyelesaian Pelayanan di Instalasi Rawat Jalan

\begin{tabular}{cc}
\hline $\begin{array}{c}\text { Jenis Pelayanan di } \\
\text { IRJ }\end{array}$ & $\begin{array}{c}\text { Respon Time } \\
\text { (Menit) }\end{array}$ \\
\hline Billing system & 15 Menit \\
Paperless & 15 Menit \\
\hline \hline \multicolumn{2}{c}{ Sumber : Profil RSUD Dr.Soetomo 2013 } \\
Secara umum pada pelayanan
\end{tabular}
instalasi rawat jalan waktu penyelesaian pelayanan pasien selama 15 menit baik di billing system atau paperless. Billing system adalah system yang berfungsi mengatur dan memproses semua tagihan yang berkaitan dengan item atau jasa yang dijual. dan khususnya di rumah sakit, itemitem tersebut lebih khusus kepada obatobatan, dan juga tindakan-tindakan medis. Paperless adalah proses dimana dokumendokumen dan data-data yang dibuat untuk ke digital maka akan dikonversi kedalam bentuk digital. Berikut ini terkait prosedur tetap (protap) pengaduan pelayanan publik RSUD Dr.Soetomo; pertama, setiap pengaduan yang masuk ke RSUD Dr.Soetomo diterima oleh petugas melalui telepon No.5501239 dan 70813188 dan dicatat data pengadu dan isi pengaduan (nama, alamat dan telepon). Kedua, pengaduan dari masyarakat yang masuk akan dipilah, apabila pengaduan dari masyarakat tersebut dapat dijawab maka petugas penerima akan menjawab pengaduan masyarakat tersebut secara langsung.

Apabila pengaduan dari masyarakat tidak dapat dijawab langsung maka pengadu masyarakat diminta 
menelpon ulang 10-60 menit kemudian. Ketiga, petugas mencari informasi langsung menghubungi sumber informasi yang dikenal dan diketahui (dokter, paramedik, staf RSUD Dr.Soetomo), sehingga pengadu sewaktu menelpon ulang petugas sudah dapat terjawab. Keempat, apabila petugas tidak dapat menjawab sumber informasi maka petugas akan berkonsultasi dengan koordinator pelayanan publik. Kelima, setelah dikonsultasikan dengan koordinator pelayanan publik dan dapat menjawab langsung pengaduan dari masyarakat maka petugas dapat menyampaikan langsung kepada pengadu. Keenam, apabila dikonsultasikan dengan koordinator pelayanan publik juga tidak dapat menjawab maka, pengadu diminta untuk menunggu selama 1-3 x 24 jam. Ketujuh, selama itu juga koordinator pelayanan publik akan mencarikan sumber informasi utama/ supervisor PKRS \& Humas. Kedelapan, setelah dari sumber informasi utama atau supervisor PKRS \& Humas atau dilakukan rapat koordinasi dari banyak bidang, jawaban akan kembali disampaikan ke koordinator pelayanan publik yang kemudian akan diinformasikan kepada petugas penerima pengaduan antuk disampaikan kembali ke pengadu. Bagi pengaduan lewat media cetak, kotak surat, website, email, facebook, akan dibuat surat jawaban tertulis ke media yang bersangkutan. Untuk kelalaian tindakan medis akan ditangani oleh komite medis sendiri. Kesembilan, jawaban kepada pengadu atau masyarakat harus disampaikan kembali maksimum dalam 5 hari kerja. Untuk jawaban yang tidak dapat diselesaikan dalam waktu 5 hari kerja, baik pengaduan secara langsung atau melalui telepon dan media cetak, website, email, facebook, maka pengadu dapat menindak lanjuti ke komisi pelayanan publik. Kesepuluh, untuk pengaduan yang tidak dapat diselesaikan akan diberikan kompensasi dengan perlakuan khusus sesuai kebijakan dari RSUD Dr.Soetomo. Kesebelas, jawaban ditulis dalam form laporan yang sudah ditetapkan. Keduabelas, semua laporan dikirim ke PKRS tiap bulan, sebelum tanggal 5 bulan berikutnya.

Tabel 2. Standar Pelayanan Minimal Instalasi Rawat Jalan

\begin{tabular}{|c|c|c|}
\hline $\begin{array}{c}\text { Jenis } \\
\text { Pelayanan }\end{array}$ & Indikator & Standar \\
\hline \multirow{6}{*}{ Rawat Jalan } & $\begin{array}{l}\text { 1. Dokter pemberi pelayanan di } \\
\text { poliklinik spesialis }\end{array}$ & $100 \%$ dokter spesialis \\
\hline & 2.Ketersediaan pelayanan & $\begin{array}{l}\text { - Klinik anak } \\
\text { - Klinik penyakit dalam } \\
\text { - Klinik kebidanan } \\
\text { - Klinik bedah }\end{array}$ \\
\hline & 3. Jam buka pelayaan & $\begin{array}{l}\text { - Pukul } 08.00 \text { sd } 13.00 \\
\text { setiap } \\
\text { hari kerja kecuali hari } \\
\text { Jumat } \\
\text { pukul } 08.00 \mathrm{sd} 11.00\end{array}$ \\
\hline & 4. Waktu tunggu di rawat jalan & $\leq 60$ menit \\
\hline & 5. Kepuasan pelanggan & $\leq 90 \%$ \\
\hline & $\begin{array}{l}\text { 6. a) Penegakan diagnosis TB melalui } \\
\text { pemeriksaan mikroskopis TB. } \\
\text { b) Terlaksananya kegiatan pencatatan dan } \\
\text { pelaporan TB di RS }\end{array}$ & \\
\hline
\end{tabular}

Sumber : SPM RS Kemenkes RI (2011). 
Di Instalasi Rawat Jalan terdapat 25 Unit Rawat Jalan yang terbagi menajdi 108 poliklinik. Rata-rata kunjungan pasien per hari mencapai 1500-3000 pasien. Program pelayanan disusun berdasarkan dua pilar yaitu (1) Service of Excellent: pelayanan prima yang diharapkan mampu memberikan kepuasan kepada customer; dan (2) Service of Champion: pelayanan maksimal/juara kepada pasien yang diharapkan membuat customer akan bersikap loyal kepada rumah sakit. Service of Champion inilah yang diejawantahkan melalui program Layanan Sepenuh Hati (LSH).

\section{Keluhan Secara Langsung}

Berikut ini adalah hasil wawancara peneliti yang berkaitan dengan keluhan pasien terhadap antrian di ruang tunggu poli instalasi rawat jalan.

"Saya pernah punya pengalaman datang pagi jam 6.30 mas, tapi poli kandungannya baru di buka jam 8.10" (Informan 7).

"Pas ngurus verifikasi berkas ke bpjs rumah sakit saya hampir ngantri 2 jam lebih mas, baru petugas yang datang cuman 3 orang, padahal yang ngantri banyak sekali"(Informan 9).

"Klo lagi rame orang datang periksa, otomatis saya sudah ngak nyaman lagi, oksigen di ruangan kurang sekali"(Informan 6).

Prosedur antrian dan berbagai permasalahan yang diperoleh dari informan dimulai dari prosedur pertama, pendaftaran atau administrasi. Pertama, masuk langsung masuk mengambil nomor antrian menggunakan nomor antrian sehingga mendapatkan nomor pelayanan. Selanjutnya pasien mengantrian pada bagian pendaftaran atau admin, disana pasien akan didata oleh petugas sebagai pasien baru, lama atau tanggungan. Berikut ini adalah hasil wawancara dengan petugas di bagian informasi unit rawat jalan RSUD Dr.Soetomo sebagai berikut : "Masingmasing poli berbeda jumlah pengunjung, nah, poli yang rame pengunjung itu mas biasanya harus menunggu lama antrian”.
"Ada pasien yang datang ke saya mengeluh, menunggu antrian di poli hingga 1 jam lebih ". "Pernah juga pasien BPJS pas awal-awal kebingungan dan marah karena harus bolak balik mengurus berkas"(informan 2 ).

Kedua, pasien diarahkan di poli-poli yang tersedia. Masalah paling krusial ada disini, dalam suatu rumah sakit ada sampai belasan poli dan terdistribusi ke tempatnya masing-masing namun disesuaikan dengan bentuk pelayanan yang diberikan, terkadang ada yang sebentar saja (10 sampai 15 menit) dan juga ada yang lebih dari itu.

Nilai estetika atau keindahan, merupakan daya tarik rumah sakit yang dapat ditangkap oleh panca indera. Misalnya keramahan petugas, peralatan rumah sakit yang lengkap dan modern, desain arsitektur rumah sakit, dekorasi kamar, kenyamanan ruang tunggu, taman yang indah dan sejuk, dan sebagainya. Hal ini menjadi kesan pertama bagi para pengunjung. Semaksimal mungkin dapat diciptakan kondisi pelayanan yang aman, nyaman dan terjangkau di rumah sakit. Berikut hasil wawancara dengan responden : "Karena ini gedung lama mas, memang banyak yang mengeluh tentang aspek kenyaman, apa itu kepanasan, lembab, dan risih. Apalagi pada jam sibuk pasien"(informan 2).

Teori antrian, yang biasa dicari adalah distribusi antar ke datangan, panjang antrian, waktu tunggu dalam sistem, dan distribusi waktu pelayanan. Selain itu, disiplin antrian yang digunakan dalam pelayanan juga dapat mempengaruhi waktu tunggu. Disiplin antrian yang umum dipakai dalam kehidupan sehari hari adalah FCFS (First Come First Serve), yaitu pertama datang pertama dilayani. Tetapi pada beberapa kejadian, disiplin antrian tersebut tidak selalu dipakai, karena alasan kebutuhan pelanggan yang harus segera ditangani. Salah satu contoh yang tidak selalu menggunakan disiplin antrian FCFS adalah antrian di rumah sakit, karena pasien yang kebutuhannya paling mendesak akan 
ditangani terlebih dulu. Disiplin antrian yang digunakan pada contoh diatas adalah (Priority Services). Pelayanan yang diprioritaskan pada pasien yang sangat membutuhkan dan perlu penanganan cepat sehingga tidak menyebabkan kerugian tersebar pada pasien.

Ketiga, setelah pemeriksaan di poli pasien diarahkan untuk mengambil obat diapotik. Pengambilan obat diapotik kadang tidak sama lamanya penyedian obat setiap pasien. Maka jika perawat lain masih meracik obat, maka pelayanan dapat dilanjutkan kembali dan jika ingin memanggil pasien dengan nomor antrian tertentu karena obat sudah selesai diracik dengan menggunakan nomor antrian yaitu menggunakan special number. Berdasarkan wawancara dengan petugas ada beberapa informasi yang diperoleh :

"Obat di BPJS ngak selengkap waktu ikut askes dulu”." Saya terkadang merasa kasian dengan pasien yang sudah tua(ngak kuat secara fisik), apalagi yang berobat dilantai 2 atau 3, mereka harus turun ke lantai dasar untuk ambil obat". "Belum lagi mereka antri lama di obat" (Informan 2).

Daftar dan harga obat serta bahan medis habis pakai (BMHP) mengacu pada ketentuan yang ditetapkan Kemenkes. Untuk daftar obat dan BMHP acuannya adalah formularium nasional (fornas) dan harganya merujuk kepada e-catalog.

\section{Keluhan Tidak Langsung}

Pada tahun 2014 total keluhan secara tidak langsung sebanyak 28 pasien sedangkan sampai dengan maret 2015 sebanyak 4 pengaduan yang masuk, sebagain besar berisi keluhan tentang
Kemenkes telah menerbitkan kebijakan yang mengatur acuan harga obat dan BMHP dilakukan secara parallel. Pola pembayaran BPJS Kesehatan, harga obat sudah termasuk dalam kapitasi dan INA-CBGs. Namun, pada masa transisi BPJS Kesehatan dan sesuai SE Menkes No. 32 Tahun 2014, ada jenis obat yang dapat ditagihkan di luar paket INA-CBGs. Yaitu pelayanan obat kronis bagi pasien yang kondisinya belum stabil dan obat kemoterapi. Berikut ini hasil wawancara dengan customer service instalasi rawat jalan RSUD Dr.Soetomo :

"Masalah persyaratan masih sangat banyak yang mengeluh, dikarenakan mereka banyak yang ngak paham, sehingga rujukan di tolak, sosialisasi masih belum masif dan merata" (informan 1).

Sosialisasi minim menyebabkan informasi yang beredar mengenai prosedur pendaftaran dan pemanfaatan pelayanan BPJS Kesehatan simpang siur dan membingungkan. Akibatnya tidak jarang staf RS yang menerima komplain atau kemarahan pasien, dituduh mempersulit, bahkan dituding mencari keuntungan. Tidak sedikit juga masyarakat mendatangi rumah sakit bukan untuk berobat melainkan untuk menanyakan mengenai BPJS, sebagaimana terjadi di RSUD Dr.Soetomo.

"Komplain dari pegawai negeri banyak juga terutama masalah obat, sangat terbatas dan ekonomis"(informan 1).

kenyamanan dan kecepatan dalam pelayanan. Kotak saran, email dan facebook terdapat keluhan pasien seputar antrian loket di counter BPJS dengan keluhan antrian yang relatif lama.

Tabel 3. Penanganan Keluhan Secara Tidak Langsung Tahun 2014

\begin{tabular}{ccc}
\hline \hline Media Penyampaian Keluhan & Jumlah & Keterangan \\
\hline \hline SMS & 18 & Tertangani Sebagian \\
Kotak Saran & 3 & Tertangani Seluruh \\
Email & 3 & Tertangani Seluruh \\
Facebook & 4 & Tertangani \\
Total & 28 & \\
\hline \hline
\end{tabular}


Berikut ini adalah alur penanganan pasien di instalasi rawat jalan RSUD Dr. Soetomo :

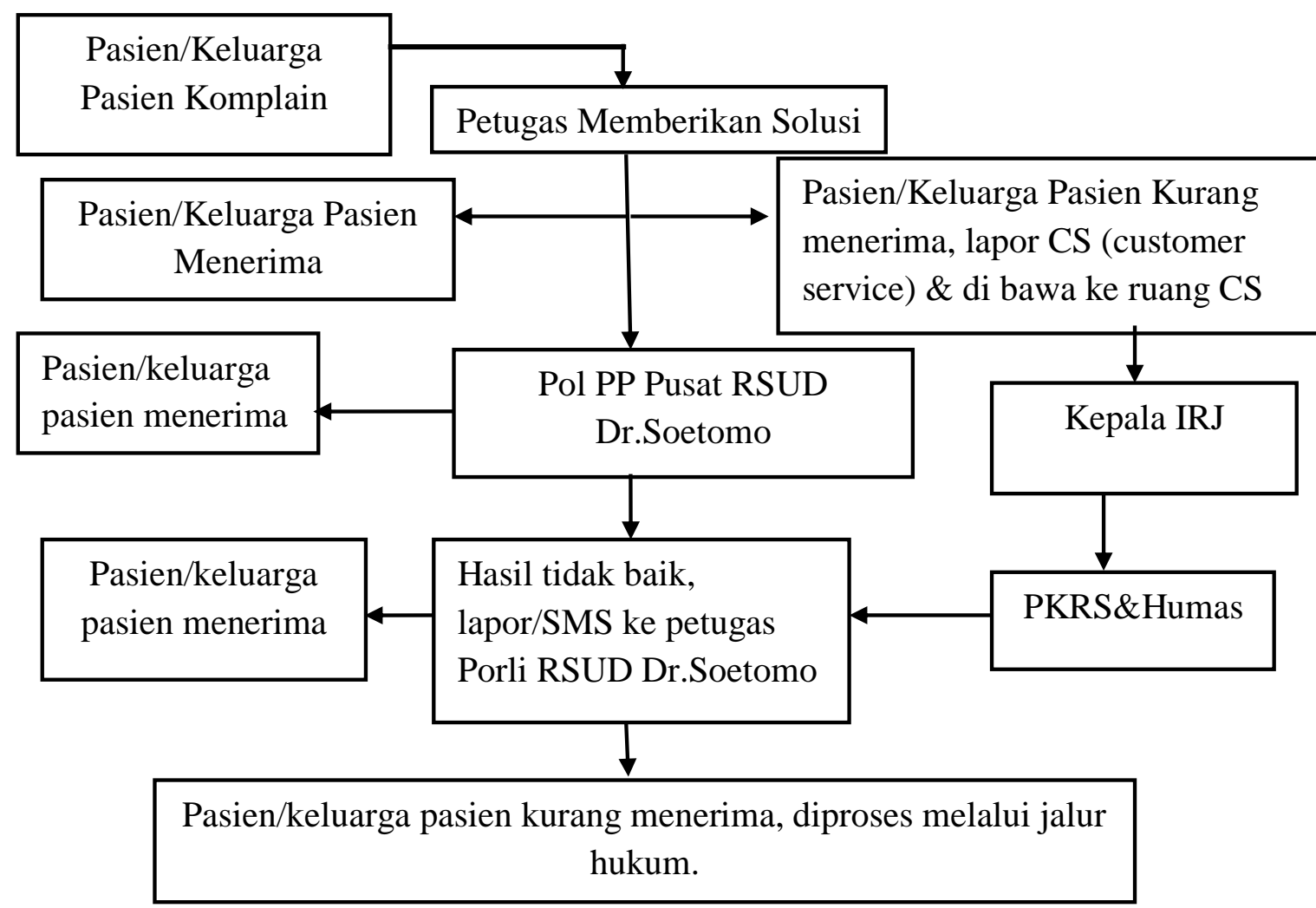

Gambar 1. Alur Penanganan Keluhan Pasien di Instalasi Rawat Jalan

Berikut ini hasil wawancara dari alur penanganan keluhan pasien :

"Sampai sekarang masih kami laksanakan prosedur ini, meskipun keluhan pasien belum sampai ke tingkat kepolisian". "Jika masalahnya lebih tinggi lagi, maka kamim akan bicarakan lagi ke PKRS ". "Prosedur ini kami tetap pegang sebagai pedoman, meskipun saya bertanggung jawab diIRJ"(Informan1).

\section{Fasilitas Penyampaian Keluhan}

Poliklinik juga berfungsi sebagai tempat untuk penemuan diagosis dini,yaitu tempat pemriksaan pasien pertama dalam rangka pemeriksaan lebih lanjut dalam tahap pengobatanpenyakit. Pelayanan rawat jalan dibagi menjadi beberapa bagian atau poliklinik, menggambarkan banyaknya pelayanan spesialistik, subspesialistik dan pelayanan gigi spesialistik dari staf medis yang ada pada rumah sakit. Fasilitas di rumah sakit masih tergolong kurang, oleh karena itu kadangkadang pasien lebih mudah langsung menghubungi media agar masalah mereka cepat tertangani dengan baik. Pengalaman selama ini menunjukan jika ada pasien yang langsung mengeluhkan permasalahan ke media, biasanya akan cepat di respon oleh pihak rumah sakit.

\section{Waktu Penyelesaian Keluhan}

Adapun standar waktu yang digunakan dalam menyelesaikan setiap keluhan yang masuk adalah sebagai berikut :

Tabel 5. Standar Waktu Pengaduan

\begin{tabular}{lcc}
\hline \hline No & Level & Waktu Penanganan \\
& Keluhan & \\
1 & Ringan & $1 \times 24$ jam \\
2 & Sedang & $3 \times 24$ jam \\
3 & Berat & $\geq 5$ hari \\
\hline \hline
\end{tabular}

Sumber : Customer Service IRJ 
Permasalahan komplain dirumah sakit memiliki tingkatan yang berbedabeda, mulai dari komplain yang sifatnya ringan atau segera bisa tertangani sampai masalah komplain yang berhubungan dengan nyawa pasien atau keselamatan. Rumah sakit harus menjelaskan bagaimana pasien dapat mengajukan keluhan tentang dimana mereka dapat melaporkan dan penjelasan dari penanganan masalah yang mereka hadapi. Sebisa mungkin proses keluhan dipermudah bagi semua pasien yang komplain. Berikut ini hasil wawancara dengan informan terkait waktu penyelesaian keluhan.

"Banyak langsung komplain ke poli atau Staff Medis Fungsional”(informan 1)

"Komplain terbanyak di pendaftaran, karena pengen cepat selesai" (informan 2)

"Untuk kasus yang masih berlanjut dapat kita tangani sampai 3 hari masa kerja, terkadang sehari"(infroman 1)

"Kasus hukum langsung kami serahkan ke KPRS secepatnya, namun selama saya bekerja cuman sekali, itupun kaitan dengan kesalahpahaman yang berujung pasiennya ngotot"(informan 1).

\section{Keluhan Pelaksanaan BPJS Kesehatan}

Selain proses registrasi yang ribet, petugas BPJS sendiri mengalami keterlambatan datang di loket. Ibarat makanan, BPJS adalah program pemerintah yang masih belum sempurna. Bagus di perencanaan, namun sedikit amburadul dalam pelaksanaan. Banyak pasien juga yang masih menggunakan askes, obat yang biasa diberikan masih bisa diklaim dan memang masih terdaftar sebagai obat yang bisa diklaimkan. Namun setelah diganti menjadi BPJS, obat yang biasa diberikan bukan lagi termasuk daftar obat yang bisa diklaimkan. Sebagaimana kasus yang sama dengan Askes, beberapa kasus dialami oleh penderita kanker payudara. Sebelumnya ketika masih menggunakan Jamkesmas, biaya operasi dan pengobatan semuanya gratis. Namun setelah diganti BPJS, biaya operasi gratis, namun beberapa biaya obat dibebankan kepada pasien. Intinya sama dengan kasus pertama, yaitu kemungkinan pengurangan daftar obat yang bisa diklaimkan.

"Semakin rumit mas ketimbang sebelum era JKN, pasien harus pake rujukan berjenjang" (informan 2 ). "Seharusnya dari puskesmas ke rumah sakit tipe $B$, kemudian baru ke tipe A, itupun klo memang belum tertangani dengan baik" (informan 2).

\section{PENUTUP \\ Simpulan}

Jenis keluhan yang disampaikan di instalasi rawat jalan RSUD Dr.Soetomo sebagain besar disampaikan secara langsung melalui tatap muka dengan petugas, baik dengan bagian informasi maupun customer service instalasi rawat jalan. Keluhan yang tidak langsung sebagian besar disampaikan melalui SMS kepada customer service.

Keluhan langsung berasal dari pasien yang mengeluhkan tentang antrian di loket terutama yang pendaftar banyak. Sebagain besar pasien juga mengeluhkan tentang penanganan parkiran meskipun bukan diluar kewenangan instalasi rawat jalan dan kenyaman ruangan di setiap loket.

Keluhan bisa saja disampaikan dimana saja, akan tetapi dengan keterbukaan informasi dan transparasi publik menuntut bagi setiap pasien yang datang memeriksakan kesehatan di poli dan mengeluhkan pelayanan dilaksanakan dengan alur yang sudah ditetapkan. Fasiltas penyampaian keluhan di instalasi RSUD Dr. Soetomo sebagain besar sudah cukup tersedia dan dipergunakan kebanyakan oleh pasien yang mengeluh terutama melalui call center yaitu telepon dan SMS.

Metode penyelesaian masalah melalui komunikasi yang efektif dan assertif sehingga dapat diselesaikan segera mungkin oleh petugas terutama dibagian informasi dan customer service berdasarkan keluhan yang diperoleh dari pasien. Sebagian besar masalah keluhan 
berasal dari kesalah pahaman dan miss komunikasi dengan pasien.

Sebagain besar pelayanan keluhan di instalasi rawat jalan RSUD Dr.Soetomo dilaksanakan segera mungkin kurang dari $1 \mathrm{x} \quad 24$ jam. Untuk kasus yang diluar wewenang instalasi rawat jalan di lanjutkan ke tingkat yang lebih tinggi lagi.Pasien lebih memilih dan merasakan lebih baik sistem pelayanan kesehatan yang lama yaitu interaksi antara provider dengan pasien langsung tanpa perantara BPJS kesehatan.

\section{Saran}

Kemajuan tehnologi informasi dan ketersedian layanan media sosial, maka keharusan untuk dilakukan penyesuaian, pengembangan dan memaksimalkan layanan keluhan berbasis media sosial, misalnya melalui facebook, twitter dll. Bukan saja pengaduan keluhan masyarakat akan tetapi tentang proses pelayanan di instalasi rawat jalan RSUD Dr.Soetomo.

Kebanyakan pasien memiliki keterbatasan informasi terkait pengaduan jika mereka mengeluhkan masalah yang berkaitan dengan pelayanan di poli rawat jalan. Maka diperlukan keterangan yang jelas dan sosialisasi tentang layanan pengaduan masyarakat baik melalui spanduk maupun poster untuk memudahkan mereka.

\section{DAFTAR PUSTAKA}

2011, Undang-Undang Nomor 24

Tahun 2011 Tentang Badan Penyelenggara Jaminan Sosial. 2012, Peraturan Pemerintah Nomor 101 Tahun 2012 Tentang Penerima Bantuan Iuran Jaminan Kesehatan.

2013, Peraturan Presiden Nomor 12 Tahun 2013 Tentang Jaminan Kesehatan Nasional, Republik Indonesia. 2008, Peraturan Menteri Kesehatan Nomor 129 Tentang Standar Pelayanan Minimal Rumah Sakit.
Afriani, N. 2012., Analisis Penanganan Keluhan Pelanggan Oleh Instalasi Pemasaran dan Humas Rumah Sakit Fatmawati. Skripsi. Depok UI.

Commonwelath Ombudmans of Australian. 2009. Better practise guide for handling complain. Commonwelath Ombudmans.

Juran, Joseph M. dan A. Blanton Godfrey. 1998. Juran's Quality Handbook, 5 th Edition. New York: Mc Graw Hill.

Kurniawan, 2007. Manajemen Keluhan Pelanggan di Rumah Sakit Umum Daerah Pangkalpinang. Universitas Gajah Madha.

RSUD Dr.Soetomo. 2013. Profil RSUD Dr. Soetomo. Surabaya.

Sri, PS., 2009. Pelayanan Instalasi Rawat Jalan RSUD DR Soetomo Dalam Perpektif Public Relation, Dinas Kominfo Kota Surabaya.

Sugiyono. 2009. Memahami Penelitian Kualitatif. Bandung: Alfabeta.

Susilo, Yudi. http :// kesehatan. kompasiana. com/medis/2014/06/11/pengelola an-obat-di-rumah-sakit 657875. html.visitasi tanggal $27 \mathrm{Mei}$ 2105.

Tjiptono, Fandy. 2008. Service Management: Mewujudkan Layanan Prima. Yogyakarta: Andi Offset.

Untoro Hario, 1997. Sistem antrian pelayanan dipoliklinik rawat jalan penyakit dalam RSUD tingkat II bekasi. Tesis. Universitas Indonesia. Depok.

Wulandari, Rafika, 2014. Gambaran Penanganan Keluhan di RSUD Pasar Rebo. Skripsi. UIN Syarifhidayatullah. Jakarta. 
Jurnal Manajemen Kesehatan STIKES Yayasan RS. Dr.Soetomo, Vol.2 No.1, April 2016 : 8-16 